\title{
Linking Porter's generic strategies to firm performance
}

\author{
Xhavit Islami ${ }^{1,2}$, Naim Mustafa ${ }^{2^{*}}$ and Marija Topuzovska Latkovikj ${ }^{3}$
}

\begin{abstract}
In this study, the significance of using Porter's generic strategies in firms that operate in competitive environments is investigated. The aim is to indicate the effects of Porter's generic strategies (low-cost strategy, differentiation strategy, and focus strategy) on firm performance. The questionnaires of the study have been prepared, the responses have been obtained, and the econometric model is constructed to measure these relationships. Findings stemmed by data that were taken from 113 firms that operate in the Republic of Kosovo. $t$ test, Pearson's correlation analysis, and multivariate regression analysis were used to provide testing of hypotheses. Econometric results suggest that pursuing differentiation strategy provides higher firm performance compared to two other Porter's generic strategies (low-cost strategy or focus strategy) that have a positive impact as well.
\end{abstract}

Keywords: Porter's generic strategies, Low-cost strategy, Differentiation strategy, Focus strategy, Firm performance

\section{Introduction}

Increasing the global market, internationalize of firms, nowadays, the uncertainty of firms is increased much more, consequently the ambiguity of firms on answering the questions, what do we have to do? and how to do it? is increased. As well as a lot of other questions that enhance the need to have a strategy, so the importance of strategy is greater today than ever before. In addition to this, it is valuable answering the question, what is the importance of having a good strategy?

The first challenge faced by firms that enter into the market is finding a way to survive in that market. Statistics and studies that are done have shown approximately one-third of new European firms do not reach the second year of their existence, whereas $50 \%-60 \%$ of them do not manage to survive till the seventh year [1].

Currently, firms are losing their energy to find methods that offer them to maintain the existing position in the market, as well as to increase the market share and profit. About $55 \%$ of new entrants fail in the first 5 years

\footnotetext{
*Correspondence: naim.mustafa@uni-gjilan.net

2 Department of Management, Faculty of Economics, University Kadri

Zeka in Gjilan, Gjilan, Republic of Kosovo

Full list of author information is available at the end of the article
}

[2]. According to Eurostat [2], about $83 \%$ of newborn enterprises in 2011 have survived in 2012, whereas over the years a gradual decrease is marked only $45 \%$ of created enterprises in 2007 which were active in 2012 . The death rate of organizations tends to decrease as they age $[3,4]$. Newly born organizations suffer a "liability of newness" [5], in which they have to learn how to survive, and must create successful patterns of operations despite having limited resources [6]. Slightly older organizations can suffer a "liability of adolescence" in which they can survive for a time on their initial store of resources, but then their failure rate tends to follow an inverted U-shaped pattern as they age [7], whereas firms in the phase of decrease try to find ways in order to have a longer life circle in the market. Older organizations can suffer a "liability of obsolescence" if their operations are highly inertial and unchanging and become increasingly misaligned with their environment [8].

So, to survive, to be more profitable, and to increase the market share, firms should create strategies. Regarding organizational strategies, organizations are referred to as "specialists" if they can survive only within a limited range of resources. However, firms are referred to as "generalists" if they can survive using a wide range of resources [9]. Empirical research has shown that 
organizations that are more generalist in nature tend to last longer than specialized organizations [10]. Generalist organizations tend to have more resources than they need for routine operations, and only operate at full capacity when responding to unanticipated environmental demands [11]. Generalist organizations also tend to introduce more new products and reach beyond their typical market segments than do specialist organizations [11]. However, the strength of generalization versus specialization can be influenced by the typical duration of environmental fluctuations [6].

Researches of this scope have shown that firms during their life cycle can be faced with strong competition that leads them to failure. This was the reason that aroused our curiosity to research the relationship between Porter's generic strategies and firm performance, as a way that can decrease the failure scale of firms. The findings of this paper enrich the strategic literature by empirical evidence and offer an opportunity for business strategists to choose the path that will provide for their organizations to survive, to increase the profit, and to increase the market share.

On these days, firms are coping with a very competitive, turbulent, and unstable market that stems from prompt technological development. Therefore, the manager's focus is on creating a competitive advantage by creating a new way of strategic development, which is appropriate for them and enables a successful adaption to that technological and industrial changes. A major stream of strategy research examines the relationship between strategy type and firm performance, which was done by [12-17]. These strategy types are sometimes called generic strategies [18].

The rest of this paper is organized as follows: The second section includes literature review regarding Porter's generic strategies that present the characteristics of low-cost strategy, differentiation strategy, and focus strategy, as well as their way of relation with firm performance. In the third section, the research hypotheses are presented, whereas the fourth section deals with the methodology used to test the raised hypotheses. In the fifth section, the model used is presented and analyzed. In the sixth section, hypotheses are tested and discussion for results is included, and this study ends with some contributive conclusions.

\section{Research objective}

After Porter's generic strategies are read and analyzed, strategists fall into confusion that which strategy should be pursued or which strategy to implement in their organization to provide better performance for their firms. Even though Porter has analyzed carefully the industry environment, competitive forces, and competitive strategies that should be built by firms to achieve competitive advantages, it lacks on presenting strategies by quantitative results, identifying how much "separately" each of the three generic strategies impacts on firm performance. As these data are missing, strategists may pursue the wrong strategy without knowing that in the long-term periods they are destructing their industry and their business as well. Therefore, to fill this gap in the literature, the objective of this study is to use the quantitative method to measure the relationship between each of the three Porter's generic strategies with firm performance, in order to enrich the existing literature and to bring something new and clearer strategy for strategists on pursuing Porter's generic strategies.

The research aim is to analyze the possible influence by implementating Porter's generic strategies: (a) low-cost strategy; (b) differentiation strategy; and (c) focus strategy in the firm performance of the production sector, and also to find out which of these three strategies is more significant with increasing firm performance.

\section{Literature review}

Since the early 1980's, Michael Porter's strategic typology has been one of the most widely accepted methods of discussing, categorizing, and selecting company strategies [19].

We focused on Porter's generic strategies' framework for a couple of reasons. Firstly, Porter's framework of generic strategies is inherently tied to firm performance. Secondly, Porter's framework overlaps with other typologies. Porter's differentiation strategy resembles [20] prospector strategy, and Porter's strategy of cost leadership is similar to Miles and Snow's defender [21, 22] cost leadership strategies. Porter's focus strategy is very much like Miller and Friesen's [23] niche innovator strategy (cited by [24]).

To make clearer the term "strategy" are presented several strategy definitions. Schendel and Hofer [25], defined strategy as: "strategy provides directional cues to the organization that permit it to achieve its objectives, while responding to the opportunities and threats in its environment." "Strategy is analyzing the present situation and changing it if necessary. Incorporated in this is finding out what one's resources are or what they should be" [26]. Cannon [27], "Strategies are the directional action decisions which are required competitively to achieve the company's purpose." Strategies are potential actions that require top management decisions and large amounts of the firm's resources [28]. In addition, strategies affect organization's long-term prosperity, typically for at least 5 years, and thus are future oriented. Strategies have 
multifunctional or multidivisional consequences and require consideration of both the external and internal factors facing the firm.

Porter's model and generic strategies are considered as an important part of management theories, through which it is explained the firm behavior toward competitors in a certain industry. The term "generic strategy" refers to a wide area of usage and opportunity to create competing advantage despite the industry, the sort, and size of organization [29]. Strategy is an essential part of any effective business plan. By using an effective competitive strategy, a company finds its industry niche and learns about its customers [18]. According to Porter, strategies allow organizations to gain competitive advantage from three different bases: cost leadership, differentiation, and focus $[18,30]$. Porter calls these bases generic strategies [28].

\section{Meaning of low-cost strategy relationship with firm performance}

Low-cost strategy emphasizes producing standardized products at a very low per-unit cost for consumers who are price sensitive [28]. According to Griffin [31], low-cost strategy is a strategy in which an organization attempts to gain a competitive advantage by reducing its costs below the costs of competing firms.

It is worth mentioning that according to Thompson et al. [32], a low-cost provider's foremost strategic objective is meaningfully lower costs than rivals-but not necessarily the absolutely lowest possible cost. In striving for a cost advantage over rivals, company managers must incorporate features and services that buyers consider essential.

Low-cost strategy puts importance in an increment in organizational performance. It includes the process by which the company is capable of producing or distributing goods and services with a lower cost than the competitors [33]. Porter defines a low-cost strategy as trading of standard products 30 combined with aggressive prices [18]. Pursuing low-cost strategy should be considered not as a product/service offered which is an inferior product, but as a product/service that has same comparative qualities with competitors and an appropriate price [33]. It is worth mentioning that Porter [30] has shown the relationship between low-cost strategy and firm performance, and he found that low-cost strategy is a successful way to realize stable competing advantage through reducing and controlling the cost and as a result raising organization performance.

Numerous authors explained that low-cost strategy can be defined by two alternative types (e.g., see [32, 34, 35]). Type one is a low-cost strategy that offers products or services to a wide range of customers at the lowest price available on the market. Type two is a best-value strategy that offers products or services to a wide range of customers at the best price value available on the market.

The reason that why organizations continue to pursue low-cost strategy is that it helps firms to increase their performance; for the sake of low cost, the company is capable of selling the product and service with a lower price and still providing the same level of profitability with the competitors [36], and protecting the organization from powerful suppliers by ensuring necessary flexibility inside the area of profit to cope with an increment in input prices [33], it serves as a barrier for entrants in conditions of the economic scale, control, and cutting the expenses [33,36], as well as through experience of curve [37].

Strategists should be careful about decision making to pursue the low-cost strategy, and it does not provide a permanent competitive advantage for companies that use low cost or best value. Low-cost strategy must achieve their competitive advantage in the way that is very difficult to copy or match by competitors. If the low-cost method can be found relatively easy by rivals or is inexpensive to imitate that strategy, the low-cost advantage will not last long enough to yield a valuable edge in the marketplace [28], which claims that in a manner that lowcost strategy is successful in improving organization performance, it must fulfill two ways to accomplish this: (a) perform value chain activities more efficiently than rivals and control the factors that drive the costs of value chain activities and (b) revamp the firm's overall value chain to eliminate or bypass some cost-producing activities. But, both of these steps could be imitated by competitors, and therefore, strategists should analyze in detail the competitors and their ability to respond with the same strategy, before they decide to apply the low-cost strategy. By pursuing a low-cost strategy, firms must be careful to use no such aggressive price cut which leads their profits to be low or not existing. Using this strategy constantly is mindful of technological breakthrough cost-saving or any other value chain progress by rivals that could erode or destroy the firm's competitive advantage.

A successful low-cost strategy usually infiltrates the entire firm, as evidenced by high efficiency, low overhead, limited perks, intolerance of waste, intensive screening of budget requests, wide spans of control, rewards linked to cost containment, and broad employee participation in cost control efforts [34].

\section{Can the differentiation strategy serve as a tool for increasing firm performance? Yes}

Differentiation strategy is one of Porter's key business strategies [38]. Differentiation refers to the development of a unique product or service $[28,30,33,36$, 
39-44]. Differentiation strategy is a strategy in which an organization seeks to distinguish itself from competitors through the quality of its products or services [31].

According to Porter [30], if product or service is unique, this strategy provides high customer loyalty. Therefore, if customers perceive the product or service as unique, they are loyal to the company and willing to pay the higher price for its products [40, 45]. According to Hesterley and Barney [46], differentiation of product or service is an expression of individual and group creativity inside firms, which means that the risk of imitating differentiation is depended on firms' capacity to be creative in finding methods that make the product unique. And for this strategy, Porter 30 showed the relationship with firm performance and the advantages that firms earn from pursuing differentiation strategy referring to realizing higher incomes compared with competitors because of mark trust, quality, and perception that clients have for the company product.

It is worth mentioning that even differentiation strategy does not defend the firm strategy from imitation by competitors forever, and David [34] wrote that differentiation does not guarantee competitive advantage, especially if standard products sufficiently meet customer needs or if rapid imitation by competitors is possible. According to him, successful differentiation can mean greater product flexibility, greater compatibility, lower costs, improved service, less maintenance, greater convenience, or more features.

A successful differentiation strategy allows a firm to charge a higher price for its product and to gain customer loyalty because consumers may become strongly attached to the differentiation features [28] declares that to the extent that differentiating attributes are tough for rivals to copy, a differentiation strategy will be especially effective, but the sources of uniqueness must be time-consuming, cost-prohibitive, and simply too burdensome for rivals to match. Therefore, the firm should pay attention when it decides to pursue the differentiation strategy. In their research, GuisadoGonzález et al. [47] have found that implementation of a differentiation strategy in the manufacturing innovative companies influences positively the probability of establishing agreements of $R \& D$ cooperation and innovation with other organizations.

The ways that managers can enhance differentiation based on value drivers according to Thompson et al. [32] include the following: create product features and performance attributes that appeal to a wide range of buyers; improve customer service or add extra services; invest in production-related $R \& D$ activities; strive for innovation and technological advances; pursue continuous quality improvement; increase marketing and brand-building activities; seek out high-quality inputs; and emphasize human resource management activities that improve the skills, expertise, and knowledge of company personnel.

\section{Is it possible that firms implement differentiation strategy and low-cost strategy simultaneously?}

Given the beneficial impact of both strategies on the firm competitive position, it logically will raise the question: Can a firm simultaneously implement both strategies? After all, if each strategy separately can improve firm performance, wouldn't be better for the firm to implement both of them? The answers to these questions are not compatible between authors.

According to Hesterly and Barney [48], the answer is No: These strategies cannot be implemented simultaneously. In their view, the organizational requirements of these strategies are essentially contradictory. Low-cost strategy requires simple reporting relationships, whereas product differentiation requires cross-divisional/cross-functional linkages. According to them, firms that do not make this choice of strategies (medium price, medium market share) or that attempt to implement both strategies will fail. These firms are said to be "stuck in the middle."

In the Porter strategy trade-off paradigm, opposed strategic dimensions could not be pursued at the same time without creating some sort of inefficiency in the firm's value chain $[18,43]$. This is because strategic positioning, such as differentiation and low cost, involves contradictory activities and resource allocation that are mutually exclusive. Another approach of strategy which is called "blue ocean strategy" argues the opposite; even more, they go beyond that firms can apply all these activities simultaneously: elimination, reduction, growing, and creating.

Strategic authors [49] have analyzed the "blue ocean strategy" by conducted a study of business launches in 108 companies. They found that $86 \%$ of these launches were line extensions, i.e., incremental improvements to existing industry offerings within red oceans, while a mere $14 \%$ were aimed at creating new markets or blue oceans. While line extensions in red oceans did account for $62 \%$ of the total revenues, they only delivered $39 \%$ of the total profits. By contrast, the $14 \%$ invested in creating blue oceans delivered $38 \%$ of total revenues and a startling $61 \%$ of total profits. Given that business launches included the total investments made for creating red and blue oceans (regardless of their subsequent revenue and profit consequences, including failures), the performance benefits of creating blue oceans are evident. In this explanation, blue ocean strategy looks a bit like differentiation strategy, because it creates something different from existing products. So, what is the relationship between blue ocean strategy and differentiation strategy? 
The explanation of the relationship between the blue ocean strategy and differentiation strategy is given in the following: Blue oceans are defined by untapped market space, demand creation, and the opportunity for highly profitable growth. Although some blue oceans are created well beyond existing industry boundaries, most are created from within red oceans by expanding existing industry boundaries. In blue oceans, competition is irrelevant because the rules of the game are waiting to be set. The term "blue ocean" is an analogy to describe the wider potential of market space that is vast, deep, and not yet explored. It will always be important to navigate successfully in the red ocean by outcompeting rivals [49]. So the main direction which is promoted by blue ocean strategy is to create something (product or service) different from the products or services that exist in the market.

Another question is regarding the relationship between blue ocean strategy and low-cost strategy. Is blue ocean strategy basically a low-cost strategy, i.e., is it about capturing the low end of a market with a low enough price? (www.blueoceanstrategy.com). The answer is No; blue ocean strategy pursues differentiation and low cost simultaneously by reconstructing market boundaries. A blue ocean strategic move captures the mass of target buyers not through low-cost pricing, but through strategic pricing. The key here is not to pursue pricing against the competition within an industry but to pursue pricing against substitutes and alternatives that are currently capturing the non-customers of your industry.

\section{Focus strategy in the function of improving firm performance}

Focus strategy is proposed from Porter 30 as a generic strategy, which has shown that if the firm implements the focus strategy in an appropriate way, its performance will be increased. Focus strategy is a strategy in which an organization concentrates on a specific regional market, product line, or group of buyers [31].

Through focus strategy, the company has as a purpose to serve a segment in the close market [30, 39-43, 50]. Pursuing this strategy provides firm the integration of wide range activities that are connected with differentiation and low cost in a particular segment from which company generates higher profits, and Pulaj [33] states that firms advantage during implementation of focus strategy are higher. One of the advantages is firm's capacity to act with high speed in order to adjust the changes in the environment, taste, and preferences of consumers. Focusing on a specific market with different needs from the others, it creates an advantage compared to rivals based on the knowledge and experience in fields related to competencies such as low cost or differentiation. According to David [28], a successful focus strategy depends on an industry segment that is of sufficient size, has good growth potential, and is not crucial to the success of other major competitors. Strategies such as market penetration and market development offer substantial focusing advantages.

According to authors [32, 34, 35], focus strategy has two alternative types. Type one is a low-cost focus strategy that offers products or services to a small range (niche group) of customers at the lowest price available on the market. Type two is a best-value focus strategy that offers products or services to a small range of customers at the best price value available on the market. Sometimes called "focused differentiation," the best-value focus strategy aims to offer a niche group of customers the products or services that meet their tastes and requirements better than rivals' products do.

Midsize and large firms can effectively pursue focusbased strategies only in conjunction with differentiation or cost leadership-based strategies. All firms in essence follow a differentiated strategy. Because only one firm can differentiate itself with the lowest cost, the remaining firms in the industry must find other ways to differentiate their products. Focus strategies are most effective when consumers have distinctive preferences or requirements and when rival firms are not attempting to specialize in the same target segment [28].

\section{The conceptual model derived from the relationship between Porter's generic strategies and firm performance}

The literature for strategies provides numerous theories, research methodologies, and ideas on the strategy-performance relationship [12]. Researchers have found the link between generic strategies and performance lessened by situational variables including a focus on manufacturing and profitability [51]. To investigate the generic strategies and performance link, many researchers began utilizing approaches found to be generalizable across industries, specifically those proposed by Porter $[18,30]$.

Several researchers have treated this relationship and later on were supported by other researchers (see [5258]). Some of the research supported singular generic strategies also produces results which sow seeds of doubt about the relationship between singular generic strategy and superior performance, and it appears some businesses succeed only when they combine differentiation and low-cost generic strategies [55]. Allen and Helms [12] seek further research on the relationship between strategy and firm performance, including potential moderators of this relationship, which is clearly needed in order to advance strategic theory.

Therefore starting from the existing literature for strategy, it will be presented the relation between Porter's generic strategy and firm performance. Figure 1 shows 


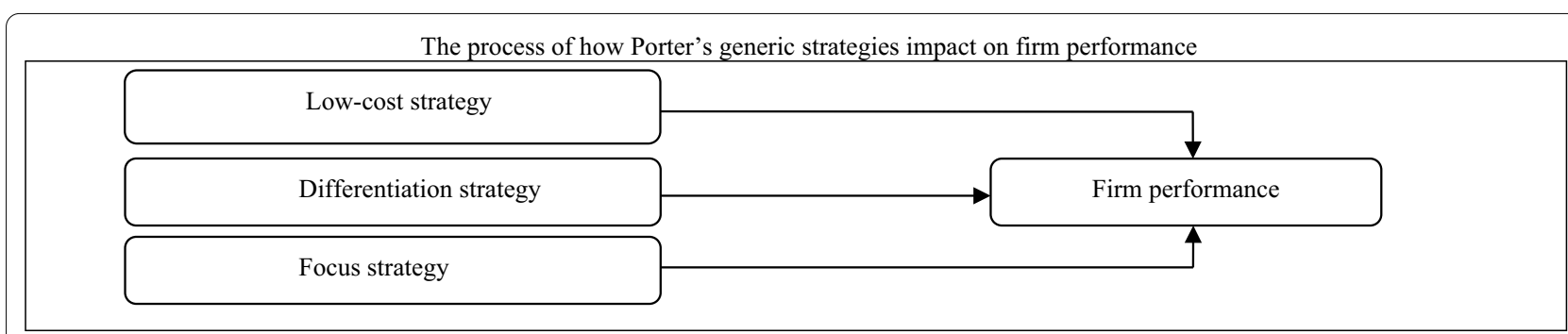

Fig. 1 Conceptual model. Source: By author

the conceptual model of this study. Authors were agreeing on the importance of generic strategies, but researchers have not determined yet, which of the three generic strategy frameworks helps more the firm to increase its performance. It seems that some combination of practices is more effective, but propositions on strategic practices have remained largely untested and there is a recognized need for empirical works in this area. This exploratory research begins to fill this gap in the literature and find out which of the three generic strategies is better to pursue by firms.

Figure 1 presents the research conceptual model, which figuratively summarizes hypotheses that will be explored below.

\section{Hypotheses and research questions}

Based on the abovementioned literature in this section, the hypotheses of the study are presented. By testing the hypotheses of this study, the gap in the existing strategic literature that deals with the relationship of linking Porter's generic strategies with firm performance will be filled. In order to provide the empirical evidence for the most important of Porter's generic strategy, which enables the firm to increase the competitive environment, the following hypotheses have to be tested:

$\mathrm{H}_{1}$ Low-cost strategy has a positive relationship with firm performance that operates in a competitive environment.

$\mathbf{H}_{2}$ Differentiation strategy has a positive relationship with firm performance that operates in a competitive environment.

$\mathbf{H}_{3} \quad$ Focus strategy has a positive relationship with firm performance that operates in a competitive environment.

By testing these hypotheses, the data will be taken for each Porter's strategy separately, but to clarify more, the aim of this paper was to create two research questions. These questions show that the study has accomplished the required rules to get the final results:
1. Are the respondent firms operating in the competitive industry? This question stresses the environment where the firms were competing, as it is well known that Porter's generic strategies are suitable only for firms that operate in the competitive industry. If the respondent firms were not operating on a competitive industry, the results of this study would not be significant for strategic literature.

2. Which of the three Porter's generic strategies has more impact on firm performance? Answering this question provides for strategists in business and academic circles the final result that is the core goal of this study. By testing the above hypotheses, the data provide whether Porter's generic strategies have a positive or negative relationship with firm performance. After results are taken from hypotheses test by the multivariate regression, the answer to this question is found out.

\section{Methodological approach}

The methodology consists of a combination of primary and secondary data that have been used to realize this study. The article has been prepared using the analysis of secondary data for literature review (scientific publications and articles from specialized databases, such as Science Direct, Springer Nature, Emerald, and other credible databases), whereas primary data in the form of the quantitative survey conducted in respondent firms that operate their business activities in the republic of Kosovo. For the empirical analysis of the study, the data were gathered by self-administered questionnaires. The participants were randomly chosen. To measure the impact between variables in this study, SPSS version 25 program has been used.

\section{Data collection}

From 150 questionnaires that in total were distributed to 150 firm's managers, only 127 valid questionnaires are obtained (so the scale of responses was $84.6 \%$ ). Even though 127 filled questionnaires were returned, 14 of 
them lacked in data and cannot be entered in the further analysis; therefore, only 113 questionnaires with full data were analyzed. The questionnaire is designed to take the evaluation of firm's managers regarding the pursuing of Porter's generic strategies in their firms. Responded firms operate in produce sector. The scale used in questionnaire is based on a five-point Likert scale (1-strongly disagree, 2-disagree, 3-neutral, 4-agree, 5-strongly agree).

The questionnaire is created based on the analysis of [28] which has shown the factors under which each of the Porter's generic strategies will be effective:

(a) Low-cost strategy can be especially effective under the following conditions (when price competition among rival sellers is especially vigorous; when the products of rival sellers are essentially identical and supplies are readily available from any of several eager sellers; when there are few ways to achieve product differentiation that have value to buyers; when most buyers use the product in the same ways; when buyers incur low costs in switching their purchases from one seller to another; when buyers are large and have significant power to bargain down prices; when industry newcomers use introductory low prices to attract buyers and build a customer base).

(b) Differentiation strategy can be especially effective under the following conditions (when there are many ways to differentiate the product or service and many buyers perceive these differences as having value; when buyer needs and uses are diverse; when few rival firms are following a similar differentiation approach; when technological change is fast paced and competition revolves around rapidly evolving product features).

(c) Focus strategy can be especially attractive under the following conditions (when the target market niche is large, profitable, and growing; when industry leaders do not consider the niche to be crucial to their own success; when industry leaders consider it too costly or difficult to meet the specialized needs of the target market niche while taking care of their mainstream customers; when the industry has many different niches and segments, thereby allowing a focuser to pick a competitively attractive niche suited to its own resources; when few, if any, other rivals are attempting to specialize in the same target segment).

Table 1 shows the factors that are included in the questionnaires that were distributed to the respondent firms, in order to make which dimensions are included within each Porter's generic strategy clear and to define factors that are directly related to pursuing the respective generic strategy. Porter's generic strategies can be particularly effective under the following conditions, and also this table helps to clarify what is meant and what items that variables have included in this study by lowcost strategy, differentiation strategy, focus strategy, and firm performance.

\section{Questionnaires as an instrument to gather data}

In order to obtain the necessary data for this research, primary sources of information were mainly used, and questionnaires were used as data collection instrument, with the target at managers or responsible of the respondent firms. Questionnaires contained four pages, and their preparation was a combination of the questionnaires that have been used for doctoral dissertations from $[33,59,60]$, followed by suggestions of three firms' managers in the produce sector and two university professors; after all the comments and suggestions are incorporated and analyzed, the final version of the questionnaire was written. The questionnaire was sent in June 2017 physically, or by electronic mail if such information was available in the databases used.

\section{Demographic data of respondents firm}

Finally, 113 questionnaires were duly completed, broken down by size and age. Table 2 shows the data of respondents concerning demographic data such as: the size, age, and the position of the questionnaire filler in the respondent firm. The questionnaires are filled by owners, directors (CEO), or managers of the respondent firms. The participants are selected randomly. The responded firms are chosen by the firms that operate in the production sector, whereas the size of respondent firms was small and medium-sized firms form $1-250^{1}$ employees.

\section{Instrument design}

To make the regression analysis, firstly we have to present the link between the independent variables, if the correlation between variables is within the limits $(-0.7$ to 0.7$)$; from the general rule of correlation, if the value is outside these limits, variables have strong connection between them, which produces incorrect estimated results. We have multicollinearity when we have a high correlation between independent variables [62-66] cited by [67].

\footnotetext{
${ }^{1}$ We have used the definition of small and medium enterprises (SME) based on European Union standards where $<10$ employees are micro-, $<50$ employees are small-, and $<250$ employees are medium-sized enterprise [61].
} 
Table 1 Summary of survey items. Source: Authors

\begin{tabular}{|c|c|}
\hline \multicolumn{2}{|c|}{ Low-cost strategy } \\
\hline $\mathrm{LCS}_{1}$ & $\begin{array}{l}\text { Insurance of raw material, negotiation about lowering prices } \\
\text { with suppliers }\end{array}$ \\
\hline $\mathrm{LCS}_{2}$ & Standardization of products/services \\
\hline $\mathrm{LCS}_{3}$ & Efficiency in products/services \\
\hline $\mathrm{LCS}_{4}$ & Maximum capacity utilization of the firm \\
\hline $\mathrm{LCS}_{5}$ & $\begin{array}{l}\text { Offering the products/services with a lower price than the } \\
\text { competitors }\end{array}$ \\
\hline $\mathrm{LCS}_{6}$ & Control of the firm's overall expenses \\
\hline \multicolumn{2}{|c|}{ Differentiation strategy } \\
\hline $\mathrm{DS}_{1}$ & Developing new products/services \\
\hline $\mathrm{DS}_{2}$ & The degree of releasing of new products/services in the market \\
\hline $\mathrm{DS}_{3}$ & Increasing the intensity of advertising and marketing \\
\hline $\mathrm{DS}_{4}$ & Differentiation through shortening the project time \\
\hline $\mathrm{DS}_{5}$ & Development and training of selling power \\
\hline $\mathrm{DS}_{6}$ & Creation of a good name and image \\
\hline $\mathrm{DS}_{7}$ & Offering unique products \\
\hline \multicolumn{2}{|c|}{ Focus strategy } \\
\hline $\mathrm{FS}_{1}$ & Aiming a specific part of the market \\
\hline $\mathrm{FS}_{2}$ & $\begin{array}{l}\text { Offering products for that segment of the market that pays } \\
\text { high prices }\end{array}$ \\
\hline $\mathrm{FS}_{3}$ & $\begin{array}{l}\text { Offering of specific products to adjust to a particular number } \\
\text { of clients }\end{array}$ \\
\hline \multicolumn{2}{|c|}{ Firm performance } \\
\hline $\mathrm{FP}_{1}$ & Increasing profit \\
\hline $\mathrm{FP}_{2}$ & Increasing incomes \\
\hline $\mathrm{FP}_{3}$ & Increasing parts of the market \\
\hline $\mathrm{FP}_{4}$ & Returning of investment (ROI) \\
\hline $\mathrm{FP}_{5}$ & Lowering costs \\
\hline $\mathrm{FP}_{6}$ & Improving quality \\
\hline
\end{tabular}

\section{The model created and variables}

In order to show the relationship between Porter's generic strategies to firm performance, in this section, an econometric model is built based on multivariate regression. This econometric model is not to sue any existing model, but it is used and presented to make our dependent and independent variables that are tested in a mathematical way clearer.

$$
\hat{Y}=\alpha+b_{1 x 1} \ldots+b_{n} x_{n}+\varepsilon_{i}
$$

where $\hat{Y}=$ dependent variable, $\alpha=$ non-standardized coefficients (constant), $b_{1 \ldots n}=$ non-standardized coefficient of variables, $x_{1 \ldots n}=$ independent variables and $\varepsilon_{i}=$ standard error.

Dependent variable "firm performance" through using non-standardized weights of regression can be presented as follows:

$$
\hat{Y}_{a}=\alpha+b_{1} \operatorname{LCS}\left(b_{1} \operatorname{lcs}_{1}+\cdots+b_{6} \operatorname{lcs}_{6}\right)+\varepsilon_{i}
$$

Table 2 Demographic characteristic of respondents. Source: Authors

\begin{tabular}{lc}
\hline Demographic variable & $\begin{array}{l}\text { Count (percentage) } \\
\boldsymbol{n}=\mathbf{1 1 3}\end{array}$ \\
\hline $\begin{array}{l}\text { Firm size } \\
\text { Up to } 49 \text { employees } \\
\text { From } 49 \text { to } 250 \text { employees }\end{array}$ & $63(55.7 \%)$ \\
Firm age & $50(44.3 \%)$ \\
$1-10$ years & $51(45.1 \%)$ \\
$11-20$ years & $36(31.8 \%)$ \\
$21-30$ years & $9(7.9 \%)$ \\
$31-40$ years & $11(9.8 \%)$ \\
Above 40 years & $6(5.4 \%)$ \\
Position of the respondents in the respondent firms \\
Owner & $12(10.6 \%)$ \\
Director (CEO) & $48(42.5 \%)$ \\
Manager & $53(46.9 \%)$ \\
\hline
\end{tabular}

$$
\begin{aligned}
& \hat{Y}_{b}=\alpha+b_{1} \mathrm{DS}\left(b_{1} \mathrm{ds}_{1}+\cdots+b_{7} \mathrm{ds}_{7}\right)+\varepsilon_{i} \\
& \hat{Y}_{c}=\alpha+b_{1} \mathrm{FS}\left(b_{1} \mathrm{fs}_{1}+\cdots+b_{3} \mathrm{fs}_{3}\right)+\varepsilon_{i}
\end{aligned}
$$

where $\hat{Y}_{a}$ is the firm performance which uses the low-cost strategy; $\hat{Y}_{b}$ is the firm performance which uses the differentiation strategy; and $\hat{Y}_{c}$ is the firm performance which uses the focus strategy.

As it can be seen even in the conceptual model shown in Fig. 1, three Porter's generic strategies have an impact on the firm performance, based on the authors [40, 55, $58,68-73]$, who have found on their research studies that a combination of these strategies may bring to the firm the best chance to achieve a higher performance; based on this, the following model ( $\hat{Y}_{\mathrm{fp}}-$ firm performance) is created:

$$
\hat{Y}_{\mathrm{fp}}=\hat{Y}_{a}+\hat{Y}_{b}+\hat{Y}_{c} \rightarrow \hat{Y}_{\mathrm{fp}}=\alpha+b_{1} \mathrm{LCS}+b_{1} \mathrm{DS}+b_{1} \mathrm{FS}+\varepsilon_{i}
$$

Independent variables: low-cost strategy (LCS), differentiation strategy (DS), and focus strategy (FS).

Dependent variables: firm performance (FP).

With SPSS software, we have tested Eqs. 2, 3, 4, and 5; the results are derived from those econometric tests.

\section{Empirical results}

Porter's generic strategies are applicable in the competitive environment; we have tested the competing environment of respondent firms. Table 3 shows the data for the competitive environment in which respondent firms operate. In the questions presented in Table 3, the participants had five scales to present their competing 
Table 3 Firm's responses for competing environment. Source: Authors

\begin{tabular}{|c|c|c|c|c|}
\hline Study of environment variables & Minimum & Maximum & Mean & Std. deviation \\
\hline A small number of firms are dominant in the market & 1 & 5 & 2.63 & 1.775 \\
\hline Products/services are similar in the market & 1 & 5 & 4.29 & 1.151 \\
\hline A large number of firms offer similar products/services & 1 & 5 & 4.26 & 1.144 \\
\hline In our industry, there is a decrease in requirement & 1 & 5 & 3.48 & 1.617 \\
\hline Obstacles to get out of market are high & 1 & 5 & 3.03 & 1.367 \\
\hline
\end{tabular}

environment from $1-$ not at all competing environment to 5-extremely competing environment. From this table, it can be seen that the highest assessment by the respondent firms has taken the ascertainment "products/ services are similar in the market" which is evaluated on average with 4.39 from 5 that was the maximal evaluation, while the lower evaluation has taken ascertainment "a small number of firms are dominant in the market" on average with 2.63 by 5 that was the maximal evaluation. By these results, the answer is found for the first research question: Are the respondent firms operating in the competitive industry? So, the environment where the respondent firms operate is a competitive environment, and these results provide the needed conditions to go further with hypotheses testing that derives by the third section of this study (Table 4).

\section{Descriptive statistics}

Descriptive data are minimum, maximum, mean, and standard deviation, for all independent variables and dependent variable that are part of this research.

A "Cronbach's alpha" test was used to evaluate the reliability of the factors as suggested by Nunnally [74] cited by [75]. Cronbach's alpha can be considered an adequate index of the inter-item consistency reliability of independent and dependent variables [76] cited by [75] Nunnally [74] suggests that constructs should have reliability values 0.7 or greater. Table 5 shows the relationship between the items that are measured, deliberately to see which factors have the highest relationship, and that can be represented by a single variable. The reliabilities for each of the four constructs were adequate since the Cronbach's alpha values for each were significantly greater than the prescribed 0.7 threshold. So, in

Table 4 Descriptive statistics of the study variables $(n=113)$. Source: Authors

\begin{tabular}{lllll}
\hline Study variables & Minimum & Maximum & Mean & Std. deviation \\
\hline LCS & 2 & 5 & 3.91 & 0.713 \\
DS & 3 & 5 & 4.29 & 0.776 \\
FS & 1 & 5 & 3.75 & 0.770 \\
FP & 2 & 5 & 3.81 & 0.991 \\
\hline
\end{tabular}

this study the values varied from 0.734 (focus strategy) to 0.894 (firm performance), showing that the instruments are sufficiently reliable. Variables $\mathrm{LCS}_{2}, \mathrm{LCS}_{4}, \mathrm{FS}_{1}$, and $\mathrm{FS}_{3}$ are moved from further analyses because they have reliability value lower than $(<0.7)$. In order to see which factors are included within each Porter's generic strategy, which enables us to test the hypotheses of this research paper, Cronbach's alpha test is performed for reliability (Table 5).

The first-order inter-items for reliability test by Cronbach's alpha found that items $\mathrm{LCS}_{2}, \mathrm{LCS}_{3}, \mathrm{FS}_{2}$, and $\mathrm{FS}_{3}$ are not related enough to put in their box of the question to test their strategy and are removed for further analysis. The differentiation strategy is represented by seven items, and all of them consisted of the level above 0.7 of the reliability test, Cronbach's alpha 0.779 . The dependent variable "firm performance" is made by six questions in the first- and second-order inter-items; the reliability results have shown a Cronbach alpha value of 0.894 , which is a high level of reliability. Based on the reliability test (Cronbach's alpha), all values were above 0.7 .

In order to analyze the data and to test the hypotheses, the correlation and regression analyses were applied. To complete the regression and correlation analysis, IMB SPSS statistical software was used. In addition to correlation and regression analyses, descriptive statistics were presented to clarify more the fitness of used variables. Whereas empirical findings presented below show the results achieved by correlation matric and regression analyse.

\section{Correlation analysis}

Table 6 shows the Pearson correlation analysis for the independent variables that are taken as a prediction in finding (defining) dependent variable "firm performance," in order to measure the scale of the relationship between independent variables in this testing. It is presented the connection between low-cost strategy, differentiation strategy, and focus strategy. According to the results presented in the table, it is shown that the relation in between independent variable is inside the allowed borders $(+,-0.7)$ [62]. The results showed no potential multicollinearity among variables. The results shown in 
Table 5 Statistical highlights-Cronbach's alpha test for reliability Source: Authors

\begin{tabular}{|c|c|c|c|c|c|c|c|}
\hline \multirow{2}{*}{\multicolumn{2}{|c|}{$\begin{array}{l}\text { Low-cost strategy } \\
\text { Cronbach's alpha test for reliabilit }\end{array}$}} & \multicolumn{2}{|c|}{ Differentiation strategy } & \multicolumn{2}{|c|}{ Focus strategy } & \multicolumn{2}{|c|}{ Firm performance } \\
\hline & & & & & & & \\
\hline 0.760 & & 0.779 & & 0.734 & & 0.894 & \\
\hline \multicolumn{8}{|c|}{ Remaining items with loading values $>0.7$} \\
\hline $\mathrm{LCS}_{1}$ & 0.767 & $\mathrm{DS}_{1}$ & 0.750 & $\mathrm{FS}_{1}$ & 0.754 & $\mathrm{PS}_{1}$ & 0.866 \\
\hline $\mathrm{LSC}_{2}$ & $0.564 x$ & $\mathrm{DS}_{2}$ & 0.750 & $\mathrm{FS}_{2}$ & $0.621 x$ & $\mathrm{PS}_{2}$ & 0.871 \\
\hline $\mathrm{LCS}_{3}$ & 0.715 & $\mathrm{DS}_{3}$ & 0.700 & $\mathrm{FS}_{3}$ & $0.619 x$ & $\mathrm{PS}_{3}$ & 0.880 \\
\hline $\mathrm{LCS}_{4}$ & $0.597 x$ & $\mathrm{DS}_{4}$ & 0.771 & & & $\mathrm{PS}_{4}$ & 0.873 \\
\hline $\mathrm{LCS}_{5}$ & 0.767 & $\mathrm{DS}_{5}$ & 0.793 & & & $\mathrm{PS}_{5}$ & 0.875 \\
\hline \multirow[t]{2}{*}{$\mathrm{LCS}_{6}$} & 0.712 & $\mathrm{DS}_{6}$ & 0.765 & & & $\mathrm{PS}_{6}$ & 0.889 \\
\hline & & $\mathrm{DS}_{7}$ & 0.712 & & & & \\
\hline
\end{tabular}

Table 6 Correlation matrix $(n=113)$. Source: Authors

\begin{tabular}{llllll}
\hline Variables & Correlations & LCS & DS & FS & FP \\
\hline LCS & $\begin{array}{l}\text { Pearson's correlation } \\
\text { Sig. (two-tailed) }\end{array}$ & & & & \\
& Pearson's correlation & $0.233^{*}$ & 1 & & \\
DS & Sig. (two-tailed) & 0.074 & & & \\
\multirow{4}{*}{ FS } & Pearson's correlation & $0.527^{* * *}$ & 0.119 & 1 & \\
& Sig. (two-tailed) & 0.000 & 0.355 & & \\
FP & Pearson's correlation & $0.499^{* * *}$ & $0.337^{* * *}$ & $0.433^{* * *}$ & 1 \\
& Sig. (two-tailed) & 0.000 & 0.007 & 0.000 & \\
\hline
\end{tabular}

*Correlation is significant at the 0.10 level (two-tailed)

***Correlation is significant at the 0.01 level (two-tailed)

Table 6 allow us to continue with further analysis to test the regression analysis.

\section{Regression analysis}

In order to measure the impact of independent variables in dependent variable "firm performance," multivariate regression analysis has been used. Regression analysis is presented in Table 7. According to regression analysis, independent variables that enter in the analysis explain $63.2 \%$ of dependent variable "firm performance." $F$ value is 9.976 (sig. 0.000), which means that the model is statistically important with the significance level $\alpha=0.05$. Independent variable "LCS" is positively connected with dependent variable "FP" by predicting it for $31.2 \%(b=0.312$ and $p=0.031)$, which means that for each $1 \%$ change in pursuing of the lowcost strategy the firm performance will change by $31.2 \%$. Independent variable "DS" is positively related to dependent variable "FP" by predicting it for $43.9 \%$ $(b=0.439$ and $p=0.019)$, which means that for each
$1 \%$ change in application of the differentiation strategy the firm performance will change by $43.9 \%$. As well, independent variable "FS" is positively related to dependent variable "FP" by predicting it for $31.5 \%$ $(b=0.315$ and $p=0.028)$, which means that for each $1 \%$ change in application of the focus strategy the firm performance will change by $31.5 \%$. If it is analyzed closely, Table 7 shows that independent variable "DS" has a higher impact in increasing firm performance compared to two other generic strategies. With these results, we answered the second research question: Which of the three Porter's generic strategies has more impact on firm performance?

Porter [18] stressed that if firms want to have a strategy in order to achieve a competitive advantage they should pursue three strategies, that he called generic strategies. In accordance with his result and based on the empirical results of this study, Eq. 6 is presented, which shows the participation of each strategy in firm performance.

$$
\begin{aligned}
\hat{Y}_{\mathrm{fp}}= & \alpha+b_{1} \mathrm{LCS}+b_{1} \mathrm{DS}+b_{1} \mathrm{FS}+\varepsilon_{i} \\
& \rightarrow \hat{Y}_{\mathrm{fp}}=0.448+0.312 * \mathrm{LCS} \\
& +0.439 * \mathrm{DS}+0.315 * \mathrm{FS}+\varepsilon_{i}
\end{aligned}
$$

As shown in Eq. 6, all the variables that were tested have a positive impact on firm performance; Porter $[18,30]$ has shown that all of his three generic strategies have a positive impact on firm performance, if those are used in the right way. Equation 6 shows something more and tells that by pursuing low-cost strategy in conditions that all the other variables remain unchanged firm performance will be increased for $31.2 \%$; by pursuing differentiation strategy in conditions that all the other variables remain unchanged firm performance will be increased for $43.9 \%$; and by pursuing focus strategy in conditions that all the other 
Table 7 Regression analysis of dependent variable "Firm performance," $n=113$. Source: Authors

\begin{tabular}{|c|c|c|c|c|c|c|c|c|}
\hline Model & $R^{2}$ & $\Delta R^{2}$ & $\beta$ & $b$ & S.E & $F$ & $t$ & $p$ \\
\hline & 0.671 & 0.632 & & & & 9.976 & & \\
\hline (Constant) & & & & 0.448 & 0.800 & & 0.560 & 0.038 \\
\hline LCS & & & 0.245 & 0.312 & 0.141 & & 2.207 & 0.031 \\
\hline DS & & & 0.312 & 0.439 & 0.182 & & 2.410 & 0.019 \\
\hline FS & & & 0.246 & 0.315 & 0.163 & & 1.934 & 0.028 \\
\hline
\end{tabular}

$b$, non-standardized coefficients; S.E, standard error of variables; $\beta$, standardized coefficients; $t, t$-statistic; $p$, significant level; $R^{2}, R$ square; $\Delta R^{2}$, adjusted $R$ square

variables remain unchanged firm performance will be increased for $31.5 \%$. In this econometric model, exactly the impact of each generic strategy in firm performance is presented, and these results have a positive impact in managers' decision making and in enriching the strategic literature related on using Porter's generic strategies and their impact on firm performance.

See the "beta" column of Table 7. If we increase using low-cost strategy by 1 standard deviation, the firm performance will increase by 0.245 standard deviations, if we increase using differentiation strategy by 1 standard deviation, the firm performance will increase by 0.312 , and if we increase using focus strategy by 1 standard deviation, the firm performance will increase by 0.246 .

\section{Discussion of the findings and their implications}

In this section, the discussion will go deeper inside Porter's generic strategies and their relationship with firm performance. Also, alternatives to pursue each of the three generic strategies and their implication on the practical implementation are presented.

The first hypothesis $\left(\mathrm{H}_{1}\right)$ has declared that low-cost strategy has a positive relationship with firm performance. The firm that pursues the low-cost strategy will increase its performance. Empirical results provided that low-cost strategy explains $31.2 \%$ of firm performance; based on this result, $\mathrm{H}_{1}$ is accepted $\left(\mathrm{H}_{1} \uparrow\right)$. The results of Table 7 show that for each 1\% of applying an increase in low-cost strategy in firm performance will be raised with $31.2 \%$ if other variables remain unchanged. This result shows that if an organization is implementing the low-cost strategy will have higher performance than its competitors that operate in the same industry but are not pursuing the low-cost strategy. The competitive advantage achieved by the low-cost strategy may be vague when competitors in the industry start to imitate that strategy. Low-cost strategy enables the firm to sell its product/service with a lower price compared to its competitors because of lower costs of producing products/service; as a result of this, they win a competitive advantage in the industry. According to Kume [36], firms that follow low-cost strategy have two advantages: (a) for the sake of low cost, firm is capable of selling products and services with lower prices than its rivalries and of having the same level of profit with them; (b) if fighting for the competition is raised, the cost leader is more resistant compared to other competitors.

The second hypothesis $\left(\mathrm{H}_{2}\right)$ has declared that differentiation strategy has a positive relationship with firm performance. The firm that pursues the differentiation strategy will increase its performance. The empirical results provided that differentiation strategy explains $43.9 \%$ of firm performance; based on this result, $\mathrm{H}_{2}$ is accepted $\left(\mathrm{H}_{2} \uparrow\right)$. For each $1 \%$ increase of applying differentiation strategy, the firm performance will be raised by $43.9 \%$ if the other variables remain unchanged. Even firms that apply differentiation strategy suffer from the imitations action by the competitors in that industry. Differentiation strategy enables firms to sell their product/service with a higher price than its competitors in the industry because firms that pursue differentiation strategy meet the needs of consummators in the way that competitors cannot fulfill; matching of these unique needs derives as a result of offering unique products or services by the firm. These firms firstly investigate the market with the aim to identify the consumers' needs and then offer the unique service/product in accordance with consumers' need.

The distinction between pursuing low-cost strategy and differentiation strategy is that: Low-cost strategy is related to economizing operations processes of productions that make possible to produce products/services with low-cost, whereas differentiation strategy is related to uniqueness of operational processes on the value chain that makes possible to produce products/services in a unique way which increases the value of its products, and as a result of this, the price of its products is increased as well.

The third hypothesis $\left(\mathrm{H}_{3}\right)$ has declared that focus strategy has a positive relation with firm performance. The firm that pursues the focus strategy will increase its performance. The empirical results provided that focus 


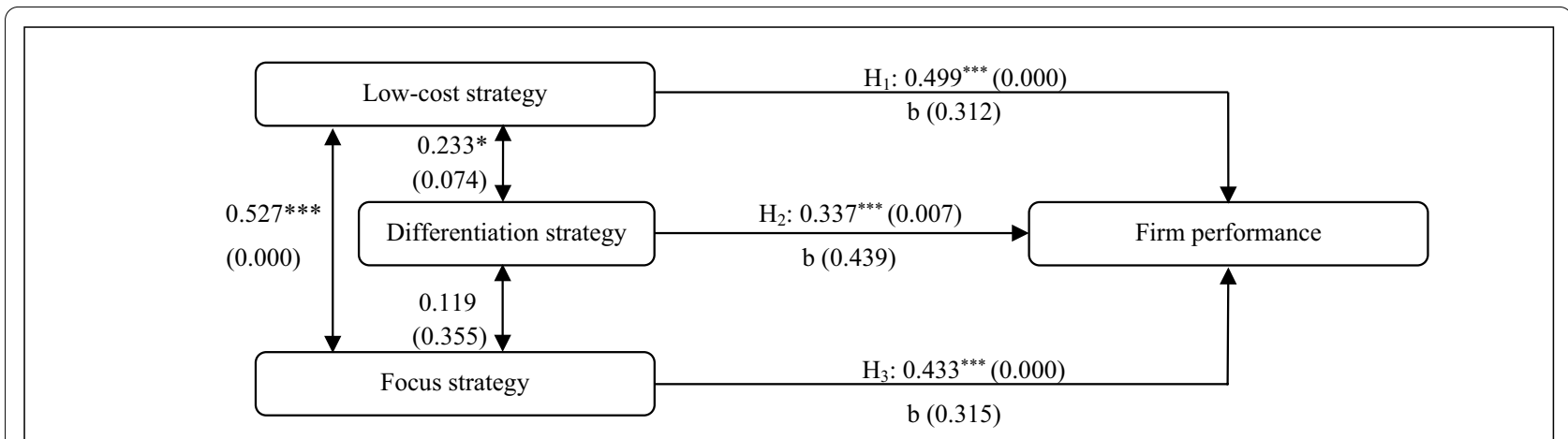

Notes: Standard deviations in parentheses. ${ }^{*} \mathrm{p}<0.10 ; * * * p<0.01 ; \mathrm{b}=$ un-standardized coefficients.

Fig. 2 Results from this study for the process of Porter's generic strategies'impact to firm performance. Notes: Standard deviations in parentheses. ${ }^{*} p<0.10 ;{ }^{* * *} p<0.01 ; b=$ non-standardized coefficients. Source: Authors

strategy explains $31.5 \%$ of firm performance; based on this result, $\mathrm{H}_{3}$ is accepted $\left(\mathrm{H}_{3} \uparrow\right)$. For each $1 \%$ increase of applying focus strategy, the firm performance will be raised by $31.5 \%$ if the other variables remain unchanged. Pursuing the focus strategy enables the firm to sell its product/service in a "niche" market that is not occupied by competitors. Focus strategy gives a competitive advantage until the moment when its competitors show interest in this part of the market. When this niche market becomes an attractive part for competitors, the firm will be faced with higher competition. In this situation, competitive firms will be forced to pursue low-cost strategy or differentiation strategy in order to survive and to increase profitability or market share.

To sum up, the application of Porter's generic strategies brought an increment to respondent firms' performance. $\mathrm{H}_{1}, \mathrm{H}_{2}$, and $\mathrm{H}_{3}$ are accepted/supported. Firms that apply low-cost strategy, differentiation strategy, and focus strategy have better performance compared to firms that do not apply Porter's generic strategies. In this study, as a result of the empirical analysis, which of the generic strategies has a higher impact on firm performance? can be identified. Results from respondent firms have shown that the firms that apply the differentiation strategy have a higher performance compared to firms that pursue the low-cost strategy or focus strategy. The visual appearance of linking Porter's generic strategies to the firm performance that is generated from the empirical analysis can be summarized as shown in Fig. 2.

Therefore, the results of this study suggest firms follow more the differentiation strategy compared to two other generic strategies. Bearing in mind the reason that, if firms apply the low-cost strategy this is going to be the first step toward the destruction of their industry in the long-term period. If one firm lowers the price for its product/service, then the competitors in that industry will apply the same strategy (lowering the price for their products/services). Low-cost strategy in a long-term period does not bring the new consumers in the industry but only bring displacement of consumers from one firm to another. As a result of this movement, zero-sum effect is created (one more customer for a firm equals to one less customer for other firms that operate in the same industry, consequently, occur customer movement between firms without bringing new clients in the industry).

On the contrary, a firm that pursues differentiation strategy in the short- and long-term period enables to increase the firm performance. In the short-term period, this method brings profit to the firm as a result of the competitive advantage that is provided by a unique product/service with higher quality than competitors. In the long-term by pursuing the differentiation strategy provides an added value of all industry. As a consequence of strategy imitation by competitors provides a higher quality of product/service that leads the industry on a higher level of quality. By analyzing very clearly, how works this strategy and what advantages it will bring in the industry? It can be explained as: the main objective of the organization managers and strategists is increasing the firm performance over time, but the existing of numerous competitors makes it not easy to achieve it. In the competitive market, the way that firm managers follow to achieve the objective is product/service differentiation, by trying to create something unique in order to be attractive for consumers. This uniqueness can be done by increasing the existing product/service values that are present in the market or bringing new and better products/services in the market. Both of these ways set a higher value of products/services in the industry.

To further simplify these implications, two levels of economic priorities, winning priorities and qualifying 
priorities, can be used. The winning priorities mean the added value of products that help firms to achieve a competitive advantage in the market, whereas qualifying priorities mean the standard value of products/services that are operating in the market. When new firms try to enter in the market, they should provide products/services at the same level of value with existing products/services in the market. In accordance with these two economic concepts, when firms pursue the differentiation strategy, the winning priorities are created which make them dominate in the competitive market, but in the long-time period, the competitors in order to compete with that industry should copy existing firms' strategy to create products/services in the same value. As a result, in the long-time period, the winning priorities become qualifying priorities; this is the reason why we stress that the value of the industry will be increased by using the differentiation strategy. Firms that pursue differentiation strategy create unique products or services that distinct those by competitors, as a result of accomplishing unique needs and demands of consummators. Our findings suggested that in an economy that competition is getting stronger, where markets are opening, competition is rising, the firms have to earn their success and in order to earn their success, they need to have a strategy, and this strategy should be the differentiation strategy. Firms must focus on bringing a unique product/service, to accomplish unique consummators needs.

\section{Conclusion}

The aim of this study was to find out the impact of Porter's generic strategies in increasing firm performance, through analyzing each of the generic strategies: low-cost strategy, differentiation strategy, and focus strategy. To find the relationship between variables of the study, three independent variables "LCS," "DS," and "FS," as well as one dependent variable "FP," were created. Three propositions have been made in the form of hypotheses: $\mathrm{H}_{1}$, $\mathrm{H}_{2}$, and $\mathrm{H}_{3}$. By the correlation analysis, the relationship between independent variables was moderated, whereas in multivariate regression analysis enough information has been found for the impact of Porter's generic strategies on firm performance. Pearson's correlation and multivariate regression results have supported three research hypotheses raised in this research.

Also, two research questions were answered in this study. The first question was answered before the hypotheses verifications and the respondent firms were operating in a competitive industry, whereas after the hypotheses were tested, the second research question was answered. The findings of this research showed that three of Porter's generic strategies are important to increase firm performance. Also, empirical findings indicated that pursuing the differentiation strategy has a higher impact on increasing firm performance compared to two other Porter's generic strategies.

Applying Porter's generic strategies provides the firms to reach successfully the essential purposes of every firm that are to survive, to be profitable, and to increase the market share. This study makes a significant contribution to the scientific and academic value, regarding the impact of Porter's generic strategies to firm performance in Kosovo, in the region, and beyond.

\section{Abbreviation \\ SPSS: Statistical Package for Social Sciences. \\ Acknowledgements \\ Not applicable.}

\section{Declarations}

This statement is to certify that all authors have seen and approved the manuscript being submitted. We warrant that the article is the authors' original work. We warrant that the article has not received prior publication and is not under consideration for publication elsewhere. On behalf of all co-authors, the corresponding author shall bear full responsibility for the submission. This research has not been submitted for publication nor has it been published in whole or in part elsewhere.

\section{Authors' contributions}

All authors read and approved the final manuscript.

\section{Funding}

The study has no funding source from any institution or donor agency.

\section{Availability of data and materials}

The data used in this manuscript are primary data, and questionnaires were used as a tool for gathering that data. The distributed questionnaires have contained the anonymity statement on it ensuring respondents that their personal data will not be published anywhere:"Anonymity: Only the investigator will have access to the physics responses. No one will be able to determine, in any written report or article, whether you have participated in this study or not, the data will be published as generalized." So, we cannot distribute their information, but we are allowed to use and to present it only in the generalized form of results. Also, SPSS is used as a tool for data analyses; as a result, those data are coded by numbers. As such, the data are in the responsibility of the corresponding author.

\section{Ethics approval and consent to participate} Not applicable.

\section{Consent for publication}

We attest to the fact that all authors have contributed significantly to the work, have read the manuscript, attest to the validity and legitimacy of the data and their interpretation, and agree for publication this manuscript in the Future Business Journal.

\section{Competing interests}

The authors confirm that there are no known conflicts of interest associated with this publication and there has been no significant financial support for this work that could have influenced its outcome.

\section{Author details}

1 Department of Organizational Science and Management (Management), Faculty of Economics, Saints Cyril and Methodius University in Skopje, Skopje, Republic of North Macedonia. ${ }^{2}$ Department of Management, Faculty of Economics, University Kadri Zeka in Gjilan, Gjilan, Republic of Kosovo. ${ }^{3}$ Centre for Management and Human Resource Development, Institute of Sociological, 
Political and Juridical Research, Saints Cyril and Methodius University in Skopje, Skopje, Republic of North Macedonia.

\section{Received: 1 August 2019 Accepted: 3 January 2020} Published: 13 January 2020

\section{References}

1. Aerts K, Matthyssens P, Vandenbempt K (2007) Critical role and screening practices of European business incubators. Technovation 27(5):254-267

2. Eurostat Statistic Explained (2016) Web: looked 22 Jan 2018. http:// ec.europa.eu/eurostat/statistics-explained/index.php/Business_demog raphy_statistics

3. Baum JAC, Oliver C (1991) Institutional linkages and organizational mortality. Adm Sci Q 36:187-218

4. Carroll GR (1983) A stochastic model of organizational mortality: review and reanalysis. Soc Sci Res 12:303-329

5. Hannan MT, Freeman J (1984) Structural inertia and organizational change. Am Sociol Rev 49:149-164

6. Hannan MT, Freeman J (1989) Organizational ecology. Harvard University Press, Cambridge

7. Fichman M, Levinthal DA (1991) Honeymoons and the liability of adolescence: a new perspective on duration dependence in social and organizational relationships. Acad Manag Rev 16:442-468

8. Barron DN, West E, Hannan MT (1994) A time to grow and a time to die: growth and mortality of credit unions in New York City, 1914-1990. Am J Sociol 100(2):381-421

9. Hannan MT, Freeman J (1977) The population ecology of organizations. Am J Sociol 82:929-964

10. Miles JA (2012) Management and organization theory: a Jossey-Bass reader, vol 9. Wiley, New York

11. Sorenson O, McEvily S, Ren CR, Roy R (2006) Niche width revisited: organizational scope, behavior and performance. Strateg Manag J 27:915-936

12. Allen RS, Helms MM (2006) Linking strategic practices and organizational performance to Porter's generic strategies. Bus Process Manag J 12(4):433-454

13. Carter NM, Stearns TM, Reynolds PD, Miller BA (1994) New venture strategies: theory development with an empirical base. Strateg Manag J 15(1):21-41

14. Kim L, Lim Y (1988) Environment, generic strategies, and performance in a rapidly developing country: a taxonomic approach. Acad Manag J 31(4):802-827

15. McDougall P, Robinson RB (1990) New venture strategies: an empirical identification of eight 'archetypes' of competitive strategies for entry. Strateg Manag J 11(6):447-467

16. Parnell JA (2011) Strategic capabilities, competitive strategy, and performance among retailers in Argentina, Peru and the United States. Manag Decis 49(1):139-155

17. Zehir C, Can E, Karaboga T (2015) Linking entrepreneurial orientation to firm performance: the role of differentiation strategy and innovation performance. Procedia Soc Behav Sci 210:358-367

18. Porter ME (1980) Competitive strategy: techniques for analyzing industries and competitors. Free Press, New York

19. Akan O, Allen RS, Helms MM, Spralls SA III (2006) Critical tactics for implementing Porter's generic strategies. J Bus Strateg 27(1):43-53

20. Miles RE, Snow CC, Meyer AD, Coleman HJ (1978) Organizational strategy, structure, and process. Acad Manag Rev 3(3):546-562

21. Dess GG, Davis PS (1984) Porter's generic strategies as determinants of strategic group membership and performance. Acad Manag J 26(3):467-488

22. Hambrick DC (1983) High profit strategies in mature capital goods industries: a contingency approach. Acad Manag J 26(4):687-707

23. Miller D, Friesen PH (1986) Porter's (1980) generic strategies and performance: an empirical examination with American data: part I_testing Porter. Organ Stud 7(1):37-55

24. Kim E, Nam DI, Stimpert JL (2004) The applicability of Porter's generic strategies in the digital age: assumptions, conjectures, and suggestions. J Manag 30(5):569-589

25. Schendel D, Hofer CW (eds) (1979) Strategic management: a new view of business policy and planning. Little, Brown, Boston
26. Drucker PF (1954) The practice of management: a study of the most important function in America society. Harper \& Brothers, New York

27. Cannon JT (1968) Business strategy and policy. Harcourt, Brace \& World, New York

28. David FR (2011) Strategic management: concepts and cases. Pearson Prentice Hall, Upper Saddle River

29. Herbert TT, Deresky H (1987) Generic strategies: an empirical investigation of typology validity and strategy content. Strateg Manag J 8(2):135-147

30. Porter ME (1985) Competitive advantage creating and sustaining superior performance. Free Press, New York

31. Griffin RW (2005) Management (eighth edition). Indian adaptation. Biztantra, New Delhi

32. Thompson AA, Strickland AJ, Gamble JE, Gao Zeng'an (2018) Crafting and executing strategy: the quest for competitive advantage-concepts and cases, 21st edn. McGraw-Hill Education, New York

33. Pulaj E (2014) Atraktiviteti i industrisë së ndërtimit nga këndvështrimi i strategjive konkurruese të porter-it. Universiteti i Tiranës - Fakulteti i ekonomisë - Departamenti i menaxhimit, Tirane

34. David FR (2017) Strategic management: concepts and cases. Pearson Prentice Hall, Upper Saddle River

35. Thomas WL, David HJ (2012) Strategic management and business policy: toward global sustainability. Columbus, Boston

36. Kume V (2010) Menaxhimi strategjik. Teori, koncepte, zbatime. (ed. i tretë) (Strategic management. Theory, concepts, implementations, 3rd ed). Pegi. Tiranë

37. Wright TP (1936) Factors affecting the cost of airplanes. J Aeronaut Sci 3(4):122-128

38. Reilly $T$ (2002) Be a champion of your solution. Ind Distrib 91(5):62

39. Bauer C, Joe C (2001) Planning for electronic commerce strategy: an explanatory study from the financial services sector. Logist Inf Manag 14(1/2):24-32

40. Cross Lisa (1999) Strategy drives marketing success. Graph Arts Mon 71(2):96

41. Porter M (1979) How competitive forces shape strategy. Harv Bus Rev 57(March-April):137-145

42. Porter M (1987) From competitive advantage to corporate strategy. Harv Bus Rev 65(May-June):43-59

43. Porter M (1996) What is strategy? Harv Bus Rev 74(November-December):61-78

44. Torgovicky R, Goldberg A, Shvarts S, Dayan YB, Onn E, Levi Y, BarDayan Y (2005) Application of Porter's generic strategies in ambulatory health care: a comparison of managerial perceptions in two Israeli sick funds. Health Care Manag Rev 30(1):17-23

45. Venu S (2001) India: competitive advantage-alternative scenarios. Business Line, Vol 12, no. 1, pp 76-89

46. Hesterly W, Barney J (2010) Strategic management and competitive advantage, Pearson edn. Pearson Prentice Hall, New York

47. Guisado-González M, Guisado-Tato M, Ferro-Soto C (2013) Business strategy and enterprises cooperation agreements in research and development. Int J Bus Innov Res 7(1):1-22

48. Hesterly B, Barney J (2008) Strategic management and competitive advantage. Pearson Prentice Hall, England

49. Chan KW, Mauborgne R (2005) Blue ocean strategy: from theory to practice. Calif Manag Rev 47(3):105-121

50. Davidson S (2001) Seizing the competitive advantage. Community Banker 10(8):32-47

51. Zahra SA (1993) Environment, corporate entrepreneurship, and financial performance: a taxonomic approach. J Bus Ventur 8(3):319-340

52. Buzzell RD, Wiersema FD (1981) successful share building strategies. Harv Bus Rev 59(1):135-144

53. Dess GG, Davis PS (1984) Porter's (1980) generic strategies as determinants of strategic group membership and organizational performance. Acad Manag J 27(3):467-488

54. Hawes JM, Crittendon WF (1984) A taxonomy of competitive retailing strategies. Strateg Manag J 5(2):275-287

55. Murray Al (1988) A contingency view of Porter's generic strategies. Acad Manag Rev 13:390-400

56. Nayyar PR (1993) On the measurement of competitive strategy: evidence from a large multiproduct US firm. Acad Manag J 36(6):1652-1669. https ://doi.org/10.2307/256825 
57. Parker B, Helms MM (1992) Generic strategies and firm performance in a declining industry. Manag Int Rev 32(1):23

58. White RE (1986) Generic business strategies, organizational context, and performance: an empirical investigation. Strateg Manag J 7(2):217-231

59. Dergjini A (2011) Menaxhimi i ndryshimeve në organizatat e biznest në Shqipëri. Desertacioni i Doktoratës. Tiranë (Change management in the Albanian organizational businesses). Doctoral dissertation, Tirana

60. Kraja YB (2014) Avantazhi konkurrues dhe roli i vlerës në suksesin e SMEve. Desertacioni i Doktoratës. Tiranë. Competitive advantages and the role of value in SME success. Doctoral dissertation, Tirana

61. European Commission (2016) Web: looked on 22 Sept 2018. http:// ec.europa.eu/growth/smes/business-friendly-environment/sme-defin ition/

62. Hair JF, Anderson RE, Tatham RL, Back WC (1998) Multivariate data analysis, 5th edn. Prentice Hall, Upper Saddle River

63. Islami X (2015) The process and techniques to overcome the resistance of change research based in the Eastern Part of Kosovo. Int J Multidiscip Curr Res 3:1122-1130

64. Islami XA, Mulolli ES, Mustafa N (2018) The effect of factors industrial and internal to the firm's performance. Acta Univ Danub Frconom 14(5):154-166

65. Islami X, Mulolli E, Mustafa N (2018) Using management by objectives as a performance appraisal tool for employee satisfaction. Fut Bus J 4(1):94-108

66. Lind DA, Marchal WG, Mason RD (2002) Statistical techniques in business and economics, 11 th edn. McGraw-Hill Irwin, New York

67. Mustafa N, Nakov L, Islami X (2019) The impact of organizational changes on increasing SMEs competitiveness. Acta Univ Danub $\mathbb{E}$ con 15(2):93-114
68. Feurer R, Chaharbaghi K (1997) Strategy development: past, present and future. Manage Decis 33(6):11-21. https://doi.org/10.1108/0025174951 0087614

69. Hlavacka S, Bacharova L, Rusnakova V, Wagner R (2001) Performance implications of Porter's generic strategies in Slovak hospitals. J Manag Med 15(1):44-66

70. Johnson G, Scholes K (1993) Exploring corporate strategy, 3rd edn. Prentice Hall International, Hertfordshire, London

71. Karnani A (1984) Generic competitive strategies-an analytical approach. Strateg Manag J 5(4):367-380

72. Matusik SF, Hill CW (1998) The utilization of contingent work, knowledge creation, and competitive advantage. Acad Manag Rev 23(4):680-697

73. Miller D (1992) The generic strategy trap. J Bus Strateg 13(1):37-41

74. Nunnally JC (1978) Psychometric theory, 2nd edn. McGraw-Hill, New York

75. Bontis N, Chua Chong Keow W, Richardson S (2000) Intellectual capital and business performance in Malaysian industries. J Intellect Cap 1(1):85-100

76. Sekaran V (1992) Research methods for business, 2nd edn. Wiley, New York

\section{Publisher's Note}

Springer Nature remains neutral with regard to jurisdictional claims in published maps and institutional affiliations.

\section{Submit your manuscript to a SpringerOpen ${ }^{\odot}$ journal and benefit from:}

- Convenient online submission

- Rigorous peer review

- Open access: articles freely available online

- High visibility within the field

- Retaining the copyright to your article

Submit your next manuscript at $\boldsymbol{\nabla}$ springeropen.com 